\title{
O bstacles to Social Workers U sing Digital Culture Skills with Members of School Activity Groups
}

\section{Hanan Ashery Abdelhafez Mohamed (PhD)}

Associate Professor Department of Social Group Work

Faculty of Developmental Social Work, Beni-Suef University

\section{Emad Gomaa A bdellatif Farag (PhD)}

Assistant Professor Department of Social Group Work Faculty of Developmental Social Work, Beni-Suef University 


\section{Abstract:}

This research attempts to define obstacles facing social workers in using skills of digital culture in social workers with school activity groups. It is a descriptive study using a sample-based survey for data collection, and applied to 209 social workers in high schools, from July to August 2020. After investigating four obstacles, no statistically significant differences were found between means of males and females in determining obstacles to skills of digital technology with activity groups. There were no statistically significant differences in means between rural and urban social workers in determining obstacles. Findings are helpful for school social workers in high schools.

Keywords: Obstacles - Social workers - Digital culture skills - School activity groups.

\section{Introduction:}

School is considered one of the first and most important fields for social work practice. Social work (SW) in schools began between 1906 and 1907 with initial development outside the school system, as a private agency and civic organization took on the work, it was not until 1913 that the first Board of Education initiated and financed a formal visiting teacher program, placing visiting teachers in special departments of the school under the administration and direction of the superintendent of schools. (Meares, Allen, 2008, p.3).

The importance of this study lies in the importance of the school field in social work in general and the method of social group work in particular. Social work with groups has been practiced in Egyptian schools since 1949 to increase the social role of schools. This is through providing students joining the school groups with experiences, human values, and social skills. The groups allow students to exercise democratic behavior in order to help them attain a sense of responsibility and respect for others and contribute to achieving the school educational goals (El Gindi, 2005, pp. 287-288).

The study is implemented during the spread of the COVID19 virus emphasizing the importance of digital skills for completing the helping process successfully with members of school activity groups. The study helps shed light on the latest trends in the practice process, i.e., digital skills, as one of the requirements of the modern era. It seeks to determine the obstacles to social workers using digital culture skills with members of school activity groups. The study utilizes the social workers' opinions to determine these obstacles. 
Activity groups are formed when students with common interests and specific hobbies join a group to engage in social, cultural, or sports activities to satisfy interests and develop hobbies (Abdel Razek, 2003, p. 674).

It is a tool the school uses for developing students' social education and to influence their character growth. The school uses it also to help students gain abilities for cooperation and leadership, and to prepare them for practicing customs and social behaviors required by the society in which they live (Tawfik, 2000, p. 434).

The importance of school activity groups lies in satisfying the students' needs and enabling them to practice activities freely, away from the constraints of school day. (Suleiman, 1990, p. 85).

An academically and professionally qualified social group worker is responsible for working with school activity groups. The social worker should have the abilities and skills to use his/her learning to help groups achieve their goals through various activities inside and outside the school (Al Gindi, 2005, p. 29).

According to the Ministry of Education statistics, the number of social workers in Egyptian schools for the academic year 2019/2020 was 149.374 spread over 509.471 schools nationwide, serving roughly 24 million students (Ministry of Education, 2019/2020).

Despite the long tradition of practicing group social work in school field in Egypt, and the large number social workers in Egyptian schools, many obstacles are facing the work of social workers, especially in light of the spread of the COVID19 virus, which required the use of skills developed on social workers, such as digital skills.

Despite the advantages of digital skills, some of its drawbacks include the need for extensive effort and training through a training plan and its association with technical factors such as the efficiency of networks, devices, and programs.

Digital technologies have revolutionized our society, and children today grow up and live in a world where these are ubiquitous. The 4th industrial revolution, the term originally coined by Schwab (2016) to describe the spread of digital technologies, affects all aspects of life, from health to commerce, from social interactions to the way people work. Education systems are no less affected, not only because technology can impact the way education is delivered, but also because education has a role to play in preparing young people for a tech-driven world (Report, 2019, p.45). 
Serpa (2019) indicates changes in the area of information and communication technologies. Three features of these technologies have played a key role: the first feature has been the large reduction in the costs of information and communication processing; the second has been the "digital convergence", led by technology, between communication and information technology; and the third has been the fast growth of international network connections. These features significantly affect all aspects of society. Moreover, as research has long shown, social workers need to acquire the necessary digital skills for their personal and professional lives. Being digitally competent and able to use digital technologies in a confident, critical, and responsible way is essential for teachers acting as role models for the future generation. However, social workers also need a set of specific competencies that will allow them to realize the potential of digital technologies in order to transform their teaching and learning. Surveys indicate, in fact, that the use of technology is to a great extent restricted to non-school, leisure time activities, while engagement with technology for educational purposes in school lags behind. (Report, 2019, p.46), Sari A.I., Suryani N., Rochsantiningsih D and Suharno S. (2020) argue that social workers should uphold the students' digital culture by integrating digital material resources and smartphone usage into classroom activities. Neden, Cleak, and Thomson (2019) indicated that the tertiary sector increasingly seeks to navigate these challenges, remain competitive, and create engaging learning through flexible, integrated, and personalized learning offerings and pathways, adopting digital learning and multi-modal designs, and by innovating in curriculum, pedagogies, and assessments.

The challenges posed by and the potential benefits of digital education in school are manifold. There is a gap to fill as an increasing number of jobs require a high level of proficiency in the use of technologies and many new jobs are based on specialized digital skills. The challenge is one of technical difficulties and increasing workload (Fang, Tarshis, McInroy, and Mishna, 2018, p.1774). In addition, Steyaert \& Gould (2009) point out that the challenge is one of digital divide between those who can use the internet and other means of communication because they possess computer tools and equipment, skills, and material ability, and those who cannot use the internet and computer equipment due to poor capabilities and skills. Panke \& Stephens (2018) indicate that the risks posed to students' personal well-being include cyber-bullying and internet addiction, as 
well as the loss of privacy. Digital skills must continue to be developed throughout life.

In the latest revision published in 2018, digital skills are defined as the ways in which digital technologies, platforms, and applications reconfigure daily lives and practices. (Reichert, Wenz, Abend, Fuchs and Richterich, 2018). Digital skills are identified as both a component of the current digital transformation of society and an epistemological obstacle toward the sociological analysis of the same phenomenon. (Sébastien, 2019, p.55).

\section{Study Concepts:}

\section{(1) Obstacle:}

Anything that gets in the way or hinders; impediment; obstacle; barrier. (Herzog, 2005, p.168)

The operational definition of an obstacle in the context of this study is:

Difficulties facing social workers as a result of the lack of knowledge and experience associated with the use of digital culture skills, which stands in the way of achieving the goals related to the professional performance of the social worker with school activity groups in virtual reality.

\section{(2) Digital Culture Skills:}

In the latest revision published in 2018, digital skills are defined as the ways in which digital technologies, platforms and applications reconfigure daily lives and practices. (Reichert, Wenz, Abend, Fuchs and Richterich, 2018).

Digital skills are identified as both a component of the current digital transformation of society and an epistemological obstacle toward the sociological analysis of the same phenomenon. (Sébastien, 2019, p.55).

A range of different abilities, many of which are not only 'skills' per se, but a combination of behaviors, expertise, know-how, work habits, character traits, dispositions, and critical understandings (Broadband commission for sustainable development 2017).

The digital culture skills cover four sub-skills: the skill of being able to use means (Digital Communication), the ability to use applications, the skill of being able to access information, and the skill of building a virtual relationship (Trilling \& Fadel 2009). 


\section{The operational definition of the Digital Culture Skills in this study is:}

A set of abilities that must be available in the social worker, which is related to a set of skills such as (using Digital communication- using applications - accessing information - building a virtual relationship).

\section{a) The Skill of Using Digital Communication:}

In this study, it means the ability of a social worker to create an active communicative environment between the social worker and members of school activity groups, using multiple communication techniques, as a way to develop their personalities or face their problems.

\section{b) The Skill of Using Digital Applications:}

In this study, it means the ability of a social worker to select and manage technological applications or programs designed for professional interventions with school activity groups.

\section{c) The Skill of Accessing Information:}

In this study, it means the ability of a social worker to interact with school activity groups. They exchange views, ideas, and conversations about their social issues in this process, using different communication channels within the ethical framework of social work.

\section{d) The Skill of Building a Virtual Relationship:}

In this study, it means the ability of a social worker to establish and develop a network of relationships and interactions among school activity groups, by using one technique or more of social media or technology to achieve their common goals.

The study problem focuses on responding to the questions: What are the obstacles for social workers using the skill of being able to use the means with members of school activity groups? What are the obstacles for social workers using the skill of being able to use applications with members of school activity groups? What are the obstacles for social workers using the skill of being able to access information with members of school activity groups? What are the obstacles for social workers using the skill to build a hypothetical relationship between the social worker and members of school activity groups? Digital skills are required for applying total quality management with members of school activity groups and using digital skills on the intellectual, psychological, and cognitive levels ensure their cooperation, reduce their resistance to the educational process, and motivate them towards innovation and excellence. This was corroborated by Report's study, which found that a large percentage 
of members of school activity groups demonstrated positive tendencies towards technology, recognizing its numerous benefits (Report 2019).

\section{Goals of the Study:}

The main goal of the study is "to identify obstacles to social workers' use of their digital culture skills with school activity groups". The following sub-goals stem from the main one:

1- to identify obstacles for social workers in using their skills of digital communication with school activity groups,

2- to identify obstacles for social workers in using their skills of digital applications with school activity groups,

3- to identify obstacles for social workers in using their skills of being able to access information with school activity groups, and

4- to identify obstacles for social workers in using their skills of building virtual relationships with school activity groups.

\section{Hypotheses of the Study:}

(1)The first hypothesis: "It is expected that the level of obstacles of social workers using digital culture skills with school activity groups to be high".

This hypothesis could be tested through testing the following dimensions:

1- obstacles for social workers in using their skills of digital communication with school activity groups,

2- obstacles for social workers in using their skills of digital applications with school activity groups,

3- obstacles for social workers in using their skills of being able to access information with school activity groups, and

4- obstacles for social workers in using their skills of building virtual relationships with school activity groups.

(2)The second hypothesis: "There are no statistically significant differences between mean scores of male and female social workers in identifying obstacles of using their digital culture skills with school activity groups".

(3)The third hypothesis: "There are no statistically significant differences between mean scores of urban and rural social workers in identifying obstacles of using their digital culture skills with school activity groups". 


\section{The Methodology:}

This is a descriptive study. It is based on a scientific approach by using a social survey by sample. The sample was drawn from social workers in a secondary school, in Beni Suef Governorate, Egypt.

Sampling: the unit of the sample was a social worker who works in a secondary school, in Beni Suef Governorate, Egypt.

Framework of Sampling: by calculating social workers in secondary stage in Beni Suef schools, they were found to be (457 units) distributed as follows:

Table (1) Distribution of social workers as the population of the study

\begin{tabular}{|c||c|c||}
\hline $\mathbf{N}$ & \multicolumn{1}{|c|}{ Description } & No. of SW \\
\hline \hline 1 & Rural & 193 \\
\hline 2 & Urban & 264 \\
\hline \hline \multicolumn{2}{|c|}{ Total } & $\mathbf{4 5 7}$ \\
\hline
\end{tabular}

(1) Type and Size of the Sample:

The study used a random sample, by the application of the principle of the best size of the sample (Dhahyan, 2002, p. 247).

The size of the sample drawn from social workers in the secondary schools in Beni Suef was (209), with a ratio of (1:2), by using the sample proportional to the size method. Their distribution was as follows:

Table (2) Distribution of social workers using the most appropriate size of the sample

\begin{tabular}{||c||c||c||c||}
\hline $\mathbf{N}$ & Description & No. of SW & $\begin{array}{c}\text { Best size of } \\
\text { sample }\end{array}$ \\
\hline \hline 1 & Rural & 193 & 88 \\
\hline \hline 2 & Urban & 264 & 121 \\
\hline \hline \multicolumn{2}{|c||}{} & Total & $\mathbf{4 5 7}$ \\
\hline
\end{tabular}

\section{Tools of the Study:}

The data-gathering tools used in this study were:

A questionnaire form to be applied to social workers. The questionnaire is about the obstacles of their use of digital culture skills when working with school activity groups.

The researcher designed an online questionnaire form using Google Drive Models for social workers about obstacles they face when using their digital culture skills with school activity groups. The design is based on his review of previous studies, and questionnaires related to the theme of the study.

Dimensions of the questionnaire items were identified into four dimensions: obstacles to using digital communication skills, 
obstacles to digital applications skills, obstacles to accessing information, and obstacles to skills of building virtual relationships.

The 32 statements of the questionnaire were identified and distributed as shown in table (3):

Table (3) Distribution of statements of social workers questionnaire

\begin{tabular}{|c|c|c|c|}
\hline $\mathbf{N}$ & Dimension & $\begin{array}{l}\text { amount of } \\
\text { items }\end{array}$ & $\begin{array}{l}\text { No. of } \\
\text { items }\end{array}$ \\
\hline 1 & $\begin{array}{l}\text { obstacles social workers face when using digital } \\
\text { communication skills }\end{array}$ & 8 & 1-8 \\
\hline 2 & obstacles of their use of digital applications skills & $\overline{88}$ & $9-16$ \\
\hline 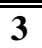 & obstacles they face to access information & 8 & 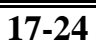 \\
\hline 4 & $\begin{array}{l}\text { obstacles of using skills of building virtual } \\
\text { relationships }\end{array}$ & 8 & 25-32 \\
\hline
\end{tabular}

- The questionnaire used a scale of three options (yes- to some extent- no). Each response was given a weight: Yes was given 3 grades; to some extent was given 2 grades; and no was given 1 grade.

- The researcher relied on the logical validity through reviewing and analyzing literature to decide on the dimensions of the studied issue.

- The researcher conducted face validity for the instrument after being reviewed by four members of university staff in the Faculty of Developmental Social Work, Beni Suef University. According to ratio of consensus, (not less than 75 percent, the questionnaire was designed in its final form).

- The two researchers also conducted statistical stability for a sample of (10) units of social workers using the Cronbach alpha coefficient, and the reliability coefficient reached (0.86), which is an appropriate level of statistical stability.

- The level of obstacles of social workers' use of digital culture skills with school activity group can be identified as the following:

Table (4) Levels of Arithmetic Means for the Obstacle of Social Workers' use of Digital Culture Skills with School Activity Groups

\begin{tabular}{||c||c||}
\hline \hline The mean value of statement or dimension from 1 to 1.67 & low level \\
\hline \hline The mean value of statement or dimension from 1.68 to 2.34 & Medium level \\
\hline \hline The mean value of a statement or dimension from 2.35 to 3 & High level \\
\hline
\end{tabular}




\section{(1) Methods of Statistical Analysis:}

The data was collected in the period from July $1^{\text {st }}, 2020$ till August $31^{\text {st }}, 2020$. The data collected was processed by SPSS.V.24.0 program. The methods used in analysis included frequencies, percentages, averages and arithmetic means, standard deviation, range, Cronbach's Alpha Coefficient, and $t$-test for two independent samples.

\section{Results of the Field Study:}

\section{Section I: Social Workers as a Research Population:}

Table (5) Description of Social Workers as a Research Population (n=209)

\begin{tabular}{|c|c|c|c|}
\hline $\mathrm{N}$ & Quantitative variables & Mean & Std. D \\
\hline 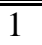 & Age & 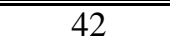 & 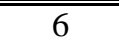 \\
\hline 2 & Years or work experience & 13 & 4 \\
\hline$\overline{\mathrm{N}}$ & $\overline{\text { Gender }}$ & Frequency & Percent \\
\hline 1 & Male & 109 & 52.2 \\
\hline 2 & Female & 100 & 47.8 \\
\hline \multicolumn{2}{|c|}{ Total } & 209 & 100 \\
\hline $\mathrm{N}$ & Qualifications & Frequency & Percent \\
\hline 1 & License of Arts, Department of Sociology & 27 & $\overline{12.9}$ \\
\hline 2 & Bachelor of Social Work & 127 & 60.8 \\
\hline 3 & Graduate Diploma in Social Work & 32 & 15.3 \\
\hline 4 & Master of Social Work & 15 & 7.2 \\
\hline$\overline{5}$ & Ph.D. of Social Work & 8 & $\overline{3.8}$ \\
\hline \multicolumn{2}{|c|}{ Total } & 209 & 100 \\
\hline $\mathrm{N}$ & Place of Residence & Frequency & Percent \\
\hline 1 & Rural & 88 & 42.1 \\
\hline 2 & Urban & 121 & $\begin{array}{l}57.9 \\
\end{array}$ \\
\hline \multicolumn{2}{|c|}{ Total } & 209 & 100 \\
\hline
\end{tabular}

This table shows that:

- The average age of social workers in the secondary stage of education is 42 years old, with standard deviation (about 6 years).

- The average years of experience among in-service school social workers in the secondary stage are 13 years, with SD about 4 years.

- The larger percentage of school social workers in the secondary stage is in favor of males $(52.2 \%)$, and females are (47.8\%).

- The largest percentages of school social workers are those with a Bachelor of Social Work $(60.8 \%)$, followed by a graduate studies diploma in Social Work (15.3\%), then a Bachelor of Arts, department of sociology (12.9\%), then a Master of Social Worker (7.2\%), and finally, who have a Ph.D. in Social Work (3.8\%). 
- The largest percentage of school social workers residing in urban areas is $(57.9 \%)$, and those living in rural areas is $(42.1 \%)$.

\section{Section II: Obstacles of Social Workers' use of digital culture skills} in Working with School Activity Groups:

\section{(1) Obstacles to Social Workers' Use of Digital Communication} Skills in Working with School Activity Groups

Table (6) Obstacles of Social Workers' use of Digital Communication Skills with School Activity Groups $(\mathbf{n}=\mathbf{2 0 9})$

\begin{tabular}{|c|c|c|c|c|}
\hline$\overline{\mathbf{N}}$ & The Phrases & Mean & Std. D & Arrange \\
\hline 1 & $\begin{array}{l}\text { Lack of a social worker's knowledge about digital } \\
\text { communication media }\end{array}$ & 2.17 & 0.65 & 5 \\
\hline 2 & $\begin{array}{l}\text { Inability of a social worker to use digital } \\
\text { communication media }\end{array}$ & 1.97 & 0.7 & 8 \\
\hline 3 & $\begin{array}{l}\text { Difficulty of communication between a social } \\
\text { worker and school activity groups through digital } \\
\text { communication media (DCM) }\end{array}$ & 2,46 & 0.66 & 4 \\
\hline 4 & Lack of funds for training on DCM & 2.85 & 0.41 & 1 \\
\hline 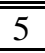 & Lack of a climate supporting the use of DCM & 2.69 & 0.54 & 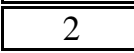 \\
\hline 6 & Lack of a social worker's skill of using DCM & 2.1 & 0.72 & 7 \\
\hline 7 & $\begin{array}{l}\text { Focusing on using the traditional methods of } \\
\text { professional practice }\end{array}$ & 2.66 & 0.56 & 3 \\
\hline 8 & $\begin{array}{l}\text { Poor communication between a social worker and } \\
\text { electronic management in school }\end{array}$ & 2.17 & 0.75 & 6 \\
\hline & The total Dimension & 2.38 & 0.35 & High \\
\hline
\end{tabular}

The table shows that the level of obstacles to a social worker's utilization of digital communication skills from their perspective is high, with an arithmetic mean of (2.38). The indicators here according to the arithmetic mean are ordered as: first, lack of funds for training on DCM with a mean of (2.85); then, lack of a climate supporting the utilization of DCM (2.69); then the $3^{\text {rd }}$ in order is focusing on using the traditional methods of professional practice (2.66); and finally, in the $8^{\text {th }}$ order is Poor communication between a social worker and electronic management in school, with an arithmetic mean of (1.97). 


\section{Obstacles to Social Workers' Use of the Digital Application Skills}

\section{in Working with School Activity Groups.}

Table (7) Obstacles to social workers' use of the digital application skills in working with school activity groups $(n=209)$

\begin{tabular}{|c|c|c|c|c|}
\hline $\mathbf{N}$ & The Phrases & \multicolumn{3}{|c|}{ 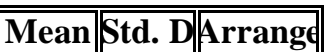 } \\
\hline 1 & 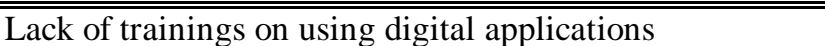 & 2.7 & 0.55 & $\overline{\overline{4}}$ \\
\hline 2 & $\begin{array}{l}\text { Lack of digital applications appropriate for school activity } \\
\text { groups }\end{array}$ & 2.76 & 0.49 & 2 \\
\hline 3 & Difficulty of using digital applications with larger groups & 2.58 & 0.6 & 5 \\
\hline 4 & Lack of criteria of using digital applications & 2.71 & 0.51 & 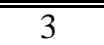 \\
\hline 5 & $\begin{array}{l}\text { Difficulty of converting social activities into digital } \\
\text { applications }\end{array}$ & 2.41 & 0.68 & 7 \\
\hline 6 & $\begin{array}{l}\text { Lack of a digital environment that can organize the jobs of } \\
\text { social workers }\end{array}$ & 2.81 & 0.45 & 1 \\
\hline$\overline{7}$ & The social workers' distrust in using digital applications & 1.86 & 0.72 & $\overline{8}$ \\
\hline 8 & $\begin{array}{l}\text { The existing programs are not based on the training needs } \\
\text { of a social worker }\end{array}$ & 2.55 & 0.6 & 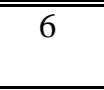 \\
\hline & The total dimension & 2.55 & $\overline{0.31}$ & High \\
\hline
\end{tabular}

\section{The above table shows that}

The level of obstacles to social workers' use of the digital application skills in working with school activity groups is high with an arithmetic mean of (2.55). The indicators of this result, according to the order of arithmetic mean are that "the lack of a digital environment organizing social workers' jobs" comes at the top with a mean of (2.81); then, at the $3^{\text {rd }}$ order, "lack of criteria for using the digital applications" with an arithmetic mean of (2.71); and finally, at the 8th order, the social worker's distrust in utilizing the digital application, with an arithmetic mean of (1.86).

\section{(2) Obstacles to Social Workers' Use of Information Accessibility Skills with School Activity Groups}

Table (8) Obstacles to Social Workers' use of information accessibility skills with school activity groups $(\mathrm{n}=209)$

\begin{tabular}{||c||l||c||c||c||}
\hline $\mathbf{N}$ & \multicolumn{1}{|c||}{ The Phrases } & Mean & Std. D & Arrang \\
\hline \hline $\mathbf{1}$ & $\begin{array}{l}\text { Difficulty of collecting data related to group } \\
\text { members through digital communication }\end{array}$ & 2.29 & 0.74 & 8 \\
\hline \hline $\mathbf{2}$ & $\begin{array}{l}\text { Group members enters with fake names in digital } \\
\text { communication media (DGM) }\end{array}$ & 2.45 & 0.73 & 6 \\
\hline \hline $\mathbf{3}$ & $\begin{array}{l}\text { Difficulty of extracting information on members } \\
\text { problems by DGM }\end{array}$ & 2.49 & 0.66 & 4 \\
\hline \hline $\mathbf{4}$ & Difficulty of applying some skills through DGM & 2.6 & 0.59 & 1 \\
\hline \hline $\mathbf{5}$ & $\begin{array}{l}\text { Difficulty in providing members with objective } \\
\text { facts about their problems on DGM }\end{array}$ & 2.54 & 0.62 & 3 \\
\hline
\end{tabular}




\begin{tabular}{|lr||}
\hline Egyptian Journal of Social Work (EJSW) & http://ejsw.journals.ekb.eg \\
ISSN: 2356-9204 & Vol 12, Issue 1, June 2021 \\
\hline \hline
\end{tabular}

\begin{tabular}{||c||c||c|c|c||}
\hline $\mathbf{N}$ & \multicolumn{1}{|c||}{ The Phrases } & Mean & Std. D & Arrang \\
\hline \hline $\mathbf{6}$ & $\begin{array}{l}\text { Difficulty of studying the problematic situation } \\
\text { through digital communication }\end{array}$ & 2.56 & 0.63 & 2 \\
\hline \hline $\mathbf{7}$ & $\begin{array}{l}\text { Lack of knowledge related to ethics of professional } \\
\text { practice through digital application }\end{array}$ & 2.42 & 0.69 & 7 \\
\hline \hline $\mathbf{8}$ & $\begin{array}{l}\text { Lack of procedures guaranteeing confidentiality of } \\
\text { data of members on DGM }\end{array}$ & 2.46 & 0.72 & 5 \\
\hline \hline \multicolumn{2}{|c|}{ Total Dimension } & $\mathbf{2 . 4 8}$ & $\mathbf{0 . 4 3}$ & $\begin{array}{l}\text { High } \\
\text { level }\end{array}$ \\
\hline
\end{tabular}

The table shows the high level of obstacles to social workers' use of information accessibility skills with an arithmetic mean of (2.48). The indicators, according to the mean order, are: first, the difficulty of applying some skills through digital communication media with a mean of (2.48); second, the difficulty of studying the problematic situation through digital communication with a mean of (2.6); third, the difficulty of providing members with objective facts about their problems through digital communication media with a mean of (2.54); and finally, at the $8^{\text {th }}$ order is difficulty of collecting data related to group members through digital communication, with a mean of (2.29).

\section{(3) Obstacles to Social Workers' Use of the Skill of Building Virtual Relationships with School Activity Groups}

Table (9) Obstacles to social workers' use of the skill of building virtual relationships with school activity groups $(n=209)$

\begin{tabular}{|c|c|c|c|c|}
\hline 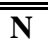 & The Phrases & Mean & Std. D & Arrange \\
\hline 1 & $\begin{array}{l}\text { Difficulty of interaction between the social worker } \\
\text { and group members on digital communication } \\
\text { media (DGM) }\end{array}$ & 2.45 & 0.67 & 5 \\
\hline 2 & $\begin{array}{l}\text { Difficulty of dealing with adolescence problems the } \\
\text { members face on DGM }\end{array}$ & 2.54 & 0.65 & $\overline{4}$ \\
\hline 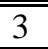 & Difficulty of studying traits of members on DGM & 2.58 & 0.62 & $\overline{3}$ \\
\hline 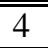 & Shyness of some members of virtual participation & 2.39 & 0.71 & $\overline{7}$ \\
\hline 5 & $\begin{array}{l}\text { Lack of social workers' absorption of building a } \\
\text { virtual relationship }\end{array}$ & 2.23 & 0.67 & $\overline{88}$ \\
\hline 6 & $\begin{array}{l}\text { Difficulty of building virtual relationships because } \\
\text { of weak internet (bandwidth) }\end{array}$ & 2.59 & 0.58 & 2 \\
\hline 7 & Difficulty of simultaneous contact on DGM & 2.44 & 0.71 & 6 \\
\hline 8 & difficulty of observing reactions on DGM & 2.72 & 0.54 & 1 \\
\hline \multicolumn{2}{|r|}{ Total Dimension } & 2.49 & (2.39 & High \\
\hline
\end{tabular}


The table shows the high level of obstacles to social workers' use of the skill of building virtual relationships among school activity groups, from social workers' perspective, since the arithmetic mean was (2.49). The indicators of this obstacle were: first, the difficulty of observing reactions of members through digital communication media, with a mean of (2.72), secondly, the difficulty of building virtual relationships because of poor internet connection (bandwidth). The third one was the difficulty of studying traits of members on digital communication media, with a mean of (2.58). Finally, as the eighth one, there was the lack of social workers' understanding of building a virtual relationship, with an arithmetic mean of (2.23).

\section{Section III: Testing Hypotheses of the Study:}

(1) Testing the first hypothesis: "It is expected that the level of obstacles to social workers using digital culture skills with school activity groups to be high."

Table (10) Level of obstacles to social workers using digital culture skills with school activity groups as a whole $(\mathrm{N}=\mathbf{2 0 9})$

\begin{tabular}{|c||c||c||c||c||c||}
\hline $\mathbf{N}$ & Obstacles & Mean & Std. D & level & Arrange \\
\hline \hline $\mathbf{1}$ & obstacles to digital communication skills & 2.38 & 0.35 & high & 4 \\
\hline \hline $\mathbf{2}$ & obstacles to digital applications skills & 2.55 & 0.31 & high & 1 \\
\hline \hline $\mathbf{3}$ & obstacles of accessing information & 2.48 & 0.43 & high & 3 \\
\hline \hline $\mathbf{4}$ & $\begin{array}{l}\text { obstacles to skills of building virtual } \\
\text { relationships }\end{array}$ & 2.49 & 0.39 & high & 2 \\
\hline \hline Total Obstacle & $\mathbf{2 . 4 7}$ & $\mathbf{0 . 2 9}$ & \multicolumn{2}{c||}{ High level } \\
\hline
\end{tabular}

The table shows that the high level of obstacles to social workers' using digital culture skills with school activity groups as a whole, from the social workers' perspective, where the arithmetic mean is (2.47). The indicators, according the descending order of mean included obstacles of using digital applications skills at the top with an arithmetic mean of (2.55). Secondly, there are the obstacles to using skills of building virtual relationships, with an arithmetic mean of (2.49). Then, as the third one, there are obstacles to social workers' ability to use their skills in accessing information, with an arithmetic mean of (2.48). Finally, there are the obstacles to using digital applications skills, with an arithmetic mean of (2.38). Accordingly, we can accept the first hypothesis of the study as stated above.

(2) Testing the second hypothesis: "There are no statistically significant differences between mean scores of male and female social workers in identifying obstacles to using their digital culture skills with school activity groups" 


\begin{tabular}{|lc||}
\hline Egyptian Journal of Social Work (EJSW) & http://ejsw.journals.ekb.eg \\
ISSN: 2356-9204 & Vol 12, Issue 1, June 2021 \\
\hline \hline
\end{tabular}

Table (11) Significant differences between mean scores of male and female social workers concerning their identification of obstacles to digital culture skills ( $\mathrm{N}=209)$

\begin{tabular}{|c|c|c|c|c|c|c|c|c|}
\hline $\mathbf{N}$ & $\begin{array}{c}\text { The } \\
\text { Dimensions }\end{array}$ & $\begin{array}{c}\text { Research } \\
\text { Community }\end{array}$ & $\overline{\mathbf{N}}$ & Mean & $\begin{array}{c}\text { Std. } \\
\text { D }\end{array}$ & 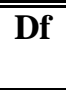 & $\begin{array}{c}\text { T- } \\
\text { Test }\end{array}$ & Sig \\
\hline & \multirow{2}{*}{$\begin{array}{l}\text { obstacles to } \\
\text { digital comm. } \\
\text { skills } \\
\end{array}$} & male & 109 & 2.4 & 0.34 & \multirow{2}{*}{207} & \multirow{2}{*}{0.549} & \multirow{2}{*}{$\begin{array}{c}\text { Not } \\
\text { significant }\end{array}$} \\
\hline 1 & & female & 100 & 2.37 & 0.37 & & & \\
\hline \multirow[b]{2}{*}{2} & \multirow{2}{*}{$\begin{array}{l}\text { obstacles of } \\
\text { using digital } \\
\text { applications } \\
\text { skills } \\
\end{array}$} & male & 109 & 2.54 & 0.33 & \multirow[b]{2}{*}{207} & \multirow[b]{2}{*}{-2.09} & \multirow[b]{2}{*}{ Not sig. } \\
\hline & & female & 100 & 2.55 & 0.29 & & & \\
\hline \multirow{2}{*}{3} & \multirow{2}{*}{$\begin{array}{l}\text { obstacles of } \\
\text { accessing } \\
\text { information }\end{array}$} & male & 109 & 2.49 & 0.43 & \multirow{2}{*}{207} & \multirow{2}{*}{0.494} & \multirow{2}{*}{ Not sig. } \\
\hline & & female & 100 & 2.46 & 0.44 & & & \\
\hline \multirow[b]{2}{*}{4} & \multirow{2}{*}{$\begin{array}{l}\text { Obstacles of the } \\
\text { skill of building } \\
\text { virtual } \\
\text { relationships }\end{array}$} & male & 109 & 2.52 & 0.34 & \multirow[b]{2}{*}{207} & \multirow[b]{2}{*}{1.205} & \multirow[b]{2}{*}{ Not sig. } \\
\hline & & female & 100 & 2.46 & 0.42 & & & \\
\hline & \multirow{2}{*}{ Total obstacles } & male & 109 & 2.49 & 0.28 & \multirow{2}{*}{207} & \multirow{2}{*}{0.703} & \multirow{2}{*}{ Not sig. } \\
\hline & & female & 100 & 2.46 & 0.29 & & & \\
\hline
\end{tabular}

**Significant at 0.01

* significant at .05

The table shows that there are no statistically significant differences between mean scores of male and female social workers concerning the obstacles to using their digital culture skills in working with school activity groups on the four kinds of obstacles mentioned in the table. This leads us to accept the second hypothesis as stated above.

(3) Testing the third hypothesis: "There are no statistically significant differences between mean scores of urban and rural social workers in identifying obstacles to using their digital culture skills with school activity groups".

Table (12) Significant differences between mean scores of social workers living in urban areas and those living in rural areas, concerning their identification of using their digital culture skills with school activity groups $(\mathbf{n}=209)$

\begin{tabular}{|c|c|c|c|c|c|c|c|c|}
\hline $\mathbf{N}$ & The Dimensions & \begin{tabular}{|c|} 
Research \\
Community
\end{tabular} & $\mathbf{N}$ & Mean & $\begin{array}{c}\text { Std. } \\
\text { D }\end{array}$ & df & T-Test & Sig \\
\hline \multirow{2}{*}{1} & \multirow{2}{*}{$\begin{array}{r}\text { obstacles to digital } \\
\text { communication } \\
\text { skills } \\
\end{array}$} & rural & 88 & 2.36 & 0.33 & \multirow{2}{*}{207} & \multirow{2}{*}{$\overline{-}$} & \multirow{2}{*}{$\begin{array}{l}\text { Not } \\
\text { sig. }\end{array}$} \\
\hline & & urban & 121 & 2.4 & 0.37 & & & \\
\hline \multirow{2}{*}{2} & \multirow{2}{*}{$\begin{array}{r}\text { obstacles to digital } \\
\text { applications skills }\end{array}$} & rural & 88 & 2.53 & 0.32 & \multirow[t]{2}{*}{207} & \multirow{2}{*}{$\begin{array}{c}- \\
0.836\end{array}$} & \multirow{2}{*}{$\begin{array}{l}\text { Not } \\
\text { sig. }\end{array}$} \\
\hline & & urban & 121 & 2.56 & 0.3 & & & \\
\hline 3 & obstacles of & rural & 88 & 2.46 & 0.38 & 207 & - & Not \\
\hline
\end{tabular}




\begin{tabular}{|c|c|c|c|c|c|c|c|c|}
\hline $\mathbf{N}$ & The Dimensions & \begin{tabular}{|c|} 
Research \\
Community
\end{tabular} & $\overline{\mathbf{N}}$ & Mean & $\begin{array}{c}\text { Std. } \\
\text { D }\end{array}$ & $\overline{\text { df }}$ & T-Test & Sig \\
\hline & $\begin{array}{r}\text { accessing } \\
\text { information }\end{array}$ & urban & 121 & 2.49 & 0.47 & & 0.474 & sig. \\
\hline \multirow{2}{*}{4} & \multirow{2}{*}{\begin{tabular}{|l} 
Obstacles to skill of \\
virtual relationships
\end{tabular}} & rural & 88 & 2.52 & $\overline{\mathbf{0 . 3 3}}$ & \multirow[t]{2}{*}{207} & \multirow{2}{*}{1.022} & \multirow{2}{*}{$\begin{array}{l}\text { Not } \\
\text { sig. }\end{array}$} \\
\hline & & $\begin{array}{l}\text { urban } \\
\end{array}$ & $\overline{121}$ & $\overline{20.47}$ & $\overline{\overline{0.42}}$ & & & \\
\hline & \multirow{2}{*}{ Total Obstacles } & rural & 88 & 2.47 & 0.25 & \multirow{2}{*}{207} & \multirow{2}{*}{$\begin{array}{c}- \\
0.357\end{array}$} & \multirow{2}{*}{$\begin{array}{l}\text { Not } \\
\text { sig. }\end{array}$} \\
\hline & & Urban & $\overline{\overline{121}}$ & 2.48 & $\overline{0.31}$ & & & \\
\hline
\end{tabular}

**:Significant at (0.01)

*significant at $(\mathbf{0 . 0 5})$

The table shows that there are no statistically significant differences between mean scores of social workers living in rural areas and those living in urban ones, concerning their identification of obstacles to using their digital culture skills. This leads us to accept the third hypothesis of the study as formulated above.

\section{Discussion}

The results of the study referred to the identification of obstacles social workers face in using their digital culture skills when working with school activity groups.

The results of this study coincide with the results of some studies, but are different from those of other studies. The current study referred to obstacles related to using digital communication media. The indicators of this obstacle included lack of funds for training on digital communication media, lack of a climate supporting the use of digital communication media, focusing on using traditional methods in professional practice, and inability of a social worker to use digital communication media.

These results coincide with what Steyaert and Gould (2009) referred as to obstacles of using communication media. The current study clarified details of these obstacles using the above indicators. It also agrees with Stephens (2018) concerning the existence of obstacles faced by students in using the internet.

The current study coincides also with Neden, Cleak and Thomson (2019) concerning obstacles of using digital application, especially in the difficulty of using digital application.

The current study is the only one that has focused on demonstrating the obstacles of using digital application, which previous studies did not discuss (such as, lack of training on using digital applications; lack of digital applications appropriate for school activity groups; the difficulty in using digital applications with larger groups; lack of criteria for using digital applications; the difficulty of converting social activities to digital applications; social workers' 
distrust in using digital applications; and the lack of existing applications based on a social worker's needs). The study succeeded in describing these obstacles according to certain indicators for each obstacle as mentioned above.

The results have also referred to the obstacles social workers face in terms of the accessibility to information when working with school activity groups. The study identified eight obstacles including the difficulties of (1) collecting data about group members through digital communication, (2) using fake names online, (3) extracting information about students' problems through digital communication media, (4) applying some skills in digital communication, (5) studying a problematic situation through digital communication, (6) lack of knowledge related to ethics of professional practice through digital applications, (7) providing support to groups on the internet, and finally, (8) lack of measures to guarantee confidentiality through digital communication. This coincides with Halabuza (2014, p.23) with regard to the difficulty of collecting data about group members through digital communication and that of providing support to groups on the internet. The other six obstacles are exclusively investigated by the current study.

This study confirmed the results of Reamer (2020) that some social workers find some difficulty in interaction and building relationship with clients on the internet. However, the results related to detailed indicators of obstacles facing virtual relationships showed that the most two common obstacles are "the difficulty of observing reactions of members" and "the difficulty of building virtual relationship because of poor internet connection". This result confirms the importance of social worker's acquisition of skills necessary for building virtual relationships with school activity groups. Serpa (2019) who pointed out that a social worker should be qualified for using digital technologies asserted this. Thus, the current study suggests that the academic specialists in social work who work with groups should hold training programs. These programs should train social workers on using contemporary digital culture skills. This is also consistent with the study of Schwab (2016) that pointed out the importance of training on digital technologies.

The results of the current study contribute to show the major obstacles faced by social workers when using their digital culture skills. No other studies investigated the indicators of such skills. The obstacles included four basic ones shown in details in this study. 
The results proved the first hypothesis to be true, where the level of obstacles to social workers' use of digital culture skills with school activity groups is high.

In addition, concerning the second hypothesis, the results of the study shows that there are no statistically significant differences between score means of male and female social workers as to their identification of obstacles to using digital culture skills in working with school activity groups.

Concerning the third hypothesis, the results of the study shows that there are no statistically significant differences between score means of urban and rural social workers as to their identification of obstacles to using digital culture skills in working with school activity groups.

Because the study was applied to a randomly systematic sample of social workers in Beni Suef governorate in Egypt, it may be helpful for social workers in the secondary stage of education at the national level. The future studies can focus on training programs for social workers to develop their digital culture skills.

The researchers faced some difficulties in finishing security and administrative procedures related to data collection. They overcame these challenges with the help of interested education leaderships to enable them collect field data. This study raises new issues to be investigated in details. These issues are represented in four obstacles related to the use of digital culture skills. Future researches can deal with each obstacle separately. There is a need for conducting experimental studies for designing programs and plans that can be implemented to train social workers on using digital culture skills and examining how to deal with each obstacle. The results of this study raised the issue of integration between the parties of practice (academics and social workers) and of holding shared conferences to achieve better professional performance.

\section{References}

Abdel Razek, E. (2003), Designing the Social Responsibility Scale for Activity Groups, Cairo, Helwan University, Faculty of Social Work, Journal of Studies in Social Work and Human Sciences, Issue 15.

Antonio Lopezpelaez and Chaime Marcuello Servos (Sept. 2018): e-Social work and digital society: re-conceptualizing approaches, practices and technologies, European journal of social work, V(21), Issue( $6)$. 
Broadband commission for sustainable development (2017) . working group on education : digital skills for life and work .p 4.

Dhahyan, Saud Al-Dhayan, Izzat Abdul-Hamid Muhammad Hassan (2002): Data Processing Using SPSS 10 (Riyadh, King Fahd National Library, Systematic Research Series.

Donalda Halabuza, Ph.D., (2014): Guidelines for Social Workers' Use of Social Networking Websites, Journal of Social Work Values and Ethics, Volume 11, Number 1 .

El Gindi, K. Mohamed (2005), Social Group Work in the School Field, in Karam Mohamed El Gindi, Nasief Fahmy, Mohammed Bahaa El Din, Adel Mesherf, Amal Badr, Professional Practice Processes on Social Group Work of Method, pp. 281-314, Cairo, Zahrra Elsharq Library.

Fang. Lin, Tarshis, Sarah, McInroy. Lauren and Mishna. Faye (2018): Undergraduate Student Experiences with Text-Based Online Counselling, The British Journal of Social Work, Volume 48, Issue 6.

Mäkitalo. Åsa, Nicewonger, Todd E. and Elam. Mark (2020): DESIGNS FOR EXPERIMENTATION AND INQUIRY Approaching Learning and Knowing in Digital Transformation, London, Routledge Taylor\& Francis group.

Meares, P. Allen, (2008), School Social Work in Mizrah, Terry \& Davis, Larry, Ed. In Chief, Encyclopaedia of social work, 20th ed., Washington, DC N.A.S.W Press, Oxford University Press. Vol. 4.

Ministry of Education (2019), The Electronic Portal, Academic Year Statistics 2019/2020.

Nania, Julia, Bonella, Hal, Restuccia, Dan, and Taska, Bledi (2019): No Longer Optional: Employer Demand for Digital Skills, Burning Glass Technologies.

Neden. Jeanette, Cleak. Helen, Thomson. Sheona (2019): Towards Agility: Scaffolding Anticipative Education in Social Work, The British Journal of Social Work, bcz080.

Panke, S., \& Stephens, J. (2018). Beyond the echo chamber: Pedagogical tools for civic engagement discourse and reflection. Educational Technology \& Society, 21(1).

Reichert, Ramón, Wenz, Karin, Abend, Pablo, Fuchs, Mathias and Richterich, Annika (2018) Digital Culture \& Society (DCS) Vol. 4, Issue 2.

Report, Eurydice (2019): Digital Education at School in Europe, Europe. Eurydice Report. Luxembourg: Publications Office of the European Union.

Sari A.I., Suryani N., Rochsantiningsih D. and Suharno S. (2020) Digital Learning, Smartphone Usage, and Digital Culture in Indonesia 
Education. Integratsiya obrazovaniya = Integration of Education.; $r \leqslant(1)$.

Sébastien, Jean Guy (2019): Digital technology, digital culture and the metric/nonmetric distinction, Elsevier Inc.

Serpa, Sandro (2019): society 5,0 and sustainability digital Innovations: A social process, Journal of Organizational Culture, Communications and Conflicts, Vol, 23, Issue1.

Steyaert, Jan \& Gould, Nick (2009): Social Work and the Changing Face of the Digital Divide, The British Journal of Social Work, Volume 39, Issue 4.

Sulaiman, Adly (1990), Social Work in the Field of Education, Fayoum, Faculty of Social Work.

Tawfiq, M. Naguib (2000), School Social Service, Cairo, Anglo-Egyptian Library.

Trilling, Bernie \& Fadel, Charles (2009): 21st Century Skills: Learning for Life in Our Times, United States of America, Library of Congress Cataloging-in-Publication Data.

David A. Herzog (2005), Webster's New World College Dictionary, Canada, Wiley, Hoboken. 